\title{
ANALISIS RESPON PETANI TERHADAP KEBIJAKAN PABRIK KELAPA SAWIT (PKS) DI KECAMATAN INDRA MAKMU KABUPATEN ACEH TIMUR
}

\author{
(Farmer Response Analysis to Oil Palm Mill (OPM)Policy In Indra Makmu District, East \\ Aceh District)
}

\author{
Nova Maulida Anggriani ${ }^{1}$, Edy Marsudi $^{1}$, Sofyan $^{1 *}$ \\ ${ }^{1}$ Program Studi Agribisnis, Fakultas Pertanian, Universitas Syiah Kuala
}

\begin{abstract}
Abstrak. Dalam upaya meningkatkan mutu dan kualitas Crude Palm Oil (CPO), Pabrik Kelapa Sawit (PKS) memberikan kebijakan terkait kriteria mutu panen Tandan Buah Segar (TBS) yang menjadi syarat masuknya TBS kedalam pabrik tersebut. Tujuan penelitian ini adalah untuk mengetahui respon petani terhadap kebijakan Pabrik Kelapa Sawit (PKS) di Kecamatan Indra Makmur Kabupaten Aceh Timur, mengetahui faktor-faktor yang mempengaruhi respon petani dan mengetahui tingkat pendapatan berdasarkan respon. Metode penelitian yang digunakan adalah metode wawancara, observasi dan kuesioner dengan analisis kualitatif (deskriptif), skoring serta kuantitatif. Hasil penelitian menunjukkan respon petani kelapa sawit terhadap kebijakan pabrik kelapa sawit di Kecamatan Indra Makmur Kabupaten Aceh Timur berdasarkan penilaian 3 aspek yaitu kognitif, afektif dan psikomotorik adalah positif. Aspek kognitif sebanyak 32 petani $(59,3 \%)$, aspek Afektif sebanyak 36 petani $(66,7 \%)$ dan aspek psikomotorik sebanyak 35 petani $(64,8 \%)$. Faktor-faktor yang berpengaruh nyata terhadap respon petani adalah usia dan pendidikan dimana nilai $p$-value < nilai signifikansi yaitu untuk usia $0,019<0,05$ dan untuk pendidikan $0,004<0.05$ yaitu tolak $\mathrm{H}_{0}$ dan terima $\mathrm{H}_{\mathrm{a}}$. Sedangkan faktor pengalaman, luas lahan dan jumlah tanggungan tidak berpengaruh nyata terhadap respon petani. Tingkat pendapatan petani respon positif lebih tinggi dibandingkan petani respon negatif. Hal ini dapat dilihat dari perhitungan rata-rata pendapatan petani, yaitu Rp 478.303/ha untuk petani respon positif dan Rp 183.433/ha untuk petani respon negatif.
\end{abstract}

Kata kunci: Respon Petani, Kebijakan, Pendapatan

Abstract. In an attempt to increase the qualities of Crude Palm Oil (CPO), Oil Palm Mill (OPM) provides a policy related to the harvest quality criteria of Fresh Fruit Bunches (FFB) which is the requirement of FFB entry into the factory. The purpose of this research is to determine the response of farmers to the policy of Oil Palm Mill (OPM) in Indra Makmur Sub-district, East Aceh Regency, to know the factors that influence the farmers response and to know the level of income based on the response. The research method used are interview method, observation and questionnaire with qualitative analysis (descriptive), scoring and quantitative. The results showed the response of palm oil farmers to the policy of Oil Palm Mill (OPM) in Indra Makmur sub-district, East Aceh Regency based on 3 aspects are cognitive, affective and psychomotor is positive. Cognitive aspect are as much as 32 farmers $(59,3 \%)$, affective aspect are as much as 36 farmers $(66,7 \%)$ and psychomotor aspect are as much as 35 farmers $(64,8 \%)$. The factors have real effect to the farmer's response are age and education where $p$-value $<$ value of significance is for age $0,019<0,05$ and for education $0,004<0.05$ is reject to $\mathrm{H}_{0}$ and accept to $\mathrm{H}_{\mathrm{a}}$. Whereas the experience factor, the land of area and the number of dependents did not significantly affect to the response of farmers. Positive response level of farmer's income is higher than farmers negative response. This matter can be seen from the calculation of average farmer's incomeis Rp478.303/ha for farmers positive response and Rp183.433/ha for farmers negative response.

Keywords: Farmer Responsive, Policy, Income

\section{PENDAHULUAN}

Dalam upaya meningkatkan mutu dan kualitas Crude Palm Oil (CPO), Pabrik Kelapa Sawit (PKS) memberikan kebijakan terkait kriteria mutu panen Tandan Buah Segar (TBS) 
yang menjadi syarat masuknya TBS kedalam pabrik tersebut. Kriteria mutu panen yang telah ditetapkan ini ditujukan untuk menentukan kematangan buah yang akan menentukan hasil rendemen minyak dari buah kelapa sawit

Berdasarkan kebijakan pabrik kelapa sawit yang berpedoman kepada peraturan Menteri Pertanian nomor 14/Permentan/OT.140/2/2013, tandan buah segar yang diterima di pabrik memiliki beberapa persyaratan mutu panen. Persyaratan tersebut dibuat agar mutu dan kualitas CPO dapat dipertahankan. Mutu panen tandan buah segar didapat dari penilaian terhadap kematangan buah panen yang dilihat pada tingkat fraksi buah saat dipanen, gagang panjang atau pendek dengan ketentuan $0-2,5 \mathrm{~cm}$ dan berbentuk huruf $\mathrm{V}$, berat tandan buah segar minimal $8 \mathrm{~kg}$, jumlah dan mutu berondolan yang diserahkan serta buah menginap atau tidak (kurang dari 24 jam setelah panen)

Menanggapi kebijakan pabrik mengenai kriteria mutu panen tandan buah segar yang berlaku demi tercapainya hasil CPO yang maksimal, terdapat perbedaan perilaku petani di lapangan. Perilaku ini muncul akibat respon dari petani yang berbeda-beda. Respon petani terhadap kebijakan pabrik kelapa sawit terkait kriteria mutu panen tandan buah segar adalah kecenderungan petani terhadap kebijakan yang dapat tercermin dari sikap mental petani seperti rasa ingin tahu, rasa minat atau rasa tidak setuju dan penolakan terhadap kebijakan. Jika respon petani terhadap kebijakan pabrik kelapa sawit adalah positif, maka petani akan menerapkan kebijakan tersebut. Begitu juga sebaliknya, jika respon petani negatif maka petani akan kurang dalam mengikuti kebijakan tersebut. Respon dapat diukur dengan cara mengamati pengetahuan petani, sikap petani dan tingkah laku petani dalam penerapan kebijakan pabrik kelapa sawit.

Hasil survey awal dengan mewawancarai salah seorang pelaku dalam saluran pemasaran (touke) terdapat perbedaan harga jual tandan buah segar antara petani dan saluran pemasaran (touke). Harga jual untuk tandan buah segar yang sesuai dengan kriteria mutu panen yang ditetapkan mencapai Rp 850/kg, sedangkan harga jual untuk tandan buah segar yang tidak sesuai dengan kriteria mutu panen yang ditetapkan hanya mencapai Rp 500/kg. Perbedaan harga jual yang didapat tentu akan berdampak bagi pendapatan petani kelapa sawit.

Tujuan dilaksanakan penelitian ini adalah untuk mengetahui respon petani terhadap kebijakan Pabrik Kelapa Sawit (PKS) di Kecamatan Indra Makmu Kabupaten Aceh Timur, mengetahui apakah usia, tingkat pendidikan, pengalaman, luas lahan dan jumlah tanggungan mempengaruhi respon petani terhadap kebijakan Pabrik Kelapa Sawit (PKS) di Kecamatan Indra Makmu Kabupaten Aceh Timur dan mengetahui tingkat pendapatan berdasarkan respon petani terhadap kebijakan Pabrik Kelapa Sawit (PKS) di Kecamatan Indra Makmu Kabupaten Aceh Timur.

\section{Lokasi dan Waktu Penelitian}

\section{METODE PENELITIAN}

Penelitian ini dilakukan di perkebunan rakyat kelapa sawit desa Blang Nisam dan desa Alue Ie Mirah di Kecamatan Indra Makmu Kabupaten Aceh Timur, khususnya di desa Blang Nisam dan desa Alue Ie Mirah Penelitian ini berlangsung pada bulan Juli 2017 sampai bulan Agustus 2017.

\section{Objek dan Ruang Lingkup Penelitian}

Objek penelitian adalah petani kelapa sawit. Ruang lingkup penelitian terbatas pada respon petani terhadap kebijakan pabrik kelapa sawit, faktor yang mempengaruhinya serta tingkat pendapatan berdasarkan respon petani terhadap kebijakan pabrik kelapa sawit. 


\section{Sumber dan Metode Pengumpulan Data}

Data yang diperoleh selama proses penelitian melalui proses wawancara, observasi dan kuisioner akan dianalisis secara kualitatif (deskriptif) dan skoring serta kuantitatif. Metode kuantitatif digunakan untuk menghitung perbedaan pendapatan berdasarkan respon petani. Penggunaan metode analisis kualitatif (deskriptif) dan skoring digunakan untuk mengetahui dengan cara memberikan gambaran mengenai respon petani terhadap kebijakan pabrik kelapa sawit terkait kriteria mutu panen tandan buah segar dan faktor-faktor yang mempengaruhinya. Data yang diperolah akan ditabulasi (data disajikan dalam bentuk tabel) agar lebih mudah dipahami. Instrumen penelitian yang digunakan untuk membantu proses penelitian adalah kuisioner gabungan terbuka dan tertutup.

\section{Model Analisis}

\section{Analisis respon petani terhadap kebijakan pabrik kelapa sawit}

A. Aspek kognitif (pengetahuan) petani terhadap kebijakan pabrik kelapa sawit

1. jika responden menjawab pilihan jawaban A (tahu/ada) diberi skor 3

2. jika responden menjawab pilihan jawaban B (ragu-ragu) diberi skor 2

3. jika responden menjawab pilihan jawaban $\mathrm{C}$ (tidak tahu/tidak ada) diberi skor 1

Pertanyaan yang diajukan sebanyak 7 pertanyaan sehingga didapat skor maksimal 21 dan skor minimal 7.
a. Kategori respon positif : jika skor yang dicapai antara $14-21$
b. Kategori respon negatif : jika skor yang dicapai antara 7-13

B. Aspek afektif (sikap) petani terhadap kebijakan pabrik kelapa sawit

1. jika responden menjawab pilihan jawaban A (setuju) diberi skor 3

2. jika responden menjawab pilihan jawaban B (kurang setuju) diberi skor 2

3. jika responden menjawab pilihan jawaban $\mathrm{C}$ (tidak setuju) diberi skor 1

Pertanyaan yang diajukan sebanyak 6 pertanyaan sehingga didapat skor maksimal 18 dan skor minimal 6.
a. Kategori respon positif : jika skor yang dicapai antara $12-18$
b. Kategori respon negatif : jika skor yang dicapai antara 6-11

C. Aspek Psikomotorik (partisipasi) petani

1. Tingkat kematangan buah

$$
\begin{array}{ll}
\text { F-00, F-0, F-1 } & =1 \\
\text { F-4, F-5 } & =2 \\
\text { F-2, F-3 } & =3
\end{array}
$$

2. Berat tandan

$\begin{array}{ll}<8 \mathrm{~kg} & =1 \\ >8 \mathrm{~kg} & =2\end{array}$

3. Buah menginap atau tidak

$$
\begin{aligned}
& >24 \text { jam }=1 \\
& <24 \text { jam }=2
\end{aligned}
$$
4. Panjang gagang tandan

$$
>2.5 \mathrm{~cm} \quad=1
$$$$
0 \mathrm{~cm}-2,5 \mathrm{~cm}=2
$$

Didapat skor maksimal dari penilaian aspek psikomotorik adalah 9 dan skor minimum adalah 4.
a. Kategori respon positif
: jika skor yang dicapai antara $7-9$
b. Kategori respon negatif
: jika skor yang dicapai antara $4-6$

Selanjutnya untuk menyimpulkan seorang petani termasuk dalam kategori petani respon positif atau negatif, peneliti menghitung berdasarkan banyaknya jumlah respon positif atau negatif dari ketiga aspek penilaian (kognitif, afektif, dan psikomotorik), 
2. Faktor-faktor yang mempengaruhi respon petani terhadap Pabrik Kelapa Sawit (PKS) di Kecamatan Indra Makmu Kabupaten Aceh Timur

Untuk mengetahui faktor-faktor yang mempengaruhi respon petani, digunakan analisis regresi logistik biner. Persamaan yang digunakan adalah:

$$
\pi(x)=\frac{e^{\left(\beta_{0}+\beta_{1} x\right)}}{1+\mathrm{e}^{\left(\beta_{0}+\beta_{1} x\right)}}
$$

Dimana $\mathrm{x} \rightarrow \infty, \pi(\mathrm{x}) \downarrow 0$ ketika $\beta<0$ dan $\pi(\mathrm{x}) \uparrow 0$ ketika $\beta>0$

a. Uji Serentak (Uji G)

Uji serentak digunakan untuk mengetahui apakah variabel bebas secara simultan atau serentak berpengaruh secara signifikan atau tidak terhadap variabel terikat. Statistika uji yang digunakan untuk uji serentak adalah uji $\mathrm{G}$ atau likelihood ratio test.

b. Uji Parsial (Uji Wald)

Uji parsial adalah uji yang digunakan untuk mengetahui apakah variabel-variabel yang diteliti berpengaruh secara nyata atau tidak jika diuji secara parsial. Uji Wald digunakan karena mengacu kepada sebaran normal.

c. Uji Kesesuaian Model

Uji kesesuaian model menggunakan uji Hosmer dan Lemeshow yang digunakan untuk menguji ada atau tidaknya perbedaan yang signifikan antara model dengan nilai sampel secara statistik sehingga model sudah fit dengan data.

Secara keseluruhan, analisis regresi logistik biner dan uji signifikansi parametrik akan dianalisis dan diuji menggunakan komputer dengan aplikasi SPSS 2.1

3. Tingkat pendapatan berdasarkan respon petani terhadap kebijakan Pabrik Kelapa Sawit (PKS) di Kecamatan Indra Makmu Kabupaten Aceh Timur

Pendapatan usahatani adalah hasil yang didapatkan petani dari kegiatan usahatani dengan cara mengurangi pendapatan kotor yang diterima dengan biaya yang digunakan selama proses produksi. Adapun dalam penelitian ini, peneliti tidak menghitung biaya produksi pra panen. Peneliti hanya menghitung biaya yang dikeluarkan petani selama panen. Model analisis yang digunakan untuk mengetahui tingkat pendapatan berdasarkan respon petani (Soekartawi, 2002 dalam Arfah, 2013) adalah:

$$
\text { Pendapatan = Nilai Produksi }(\mathrm{Rp})-\text { Biaya Panen }(\mathrm{Rp})
$$

\section{HASIL PENELITIAN DAN PEMBAHASAN}

\section{Respon Petani Terhadap Kebijakan Pabrik Kelapa Sawit}

\section{A. Aspek Kognitif (Pengetahuan) Petani terhadap Kebijakan Pabrik Kelapa Sawit}

Respon petani dilihat dari aspek kognitif menyatakan lebih banyak petani yang merespon positif yaitu 32 petani $(59,3 \%)$, sedangkan sisanya yaitu 22 petani $(40,7 \%)$ merespon negative. Persentase pada kedua jenis respon tersebut didapatkan berdasarkan ratarata persentase dari pilihan jawaban yang dipilih responden, yaitu pilihan tahu/ada (54\%), pilihan ragu-ragu $(14,5 \%)$ dan pilihan tidak tahu/tidak ada $(31,5 \%)$. Berdasarkan hasil kuesioner yang telah diinput, dari 7 pertanyaan mengenai aspek kognitif yang diajukan, skor jawaban tertinggi adalah pada pertanyaan mengenai resiko yang diterima petani jika memanen tidak sesuai dengan kebijakan pabrik kelapa sawit. Jumlah skor jawaban petani untuk pertanyaan ini adalah 134. Mayoritas petani mengetahui resiko tersebut berdasarkan arahan dari touke yang membantu proses pemasaran TBS petani. Selain itu petani juga mengacu kepada pengalaman petani yang pernah dikembalikan TBS karena tidak sesuai dengan 
kebijakan pabrik seperti pemanenan TBS yang masih mentah atau berat TBS kurang dari 8 $\mathrm{Kg}$.

Pertanyaan yang diajukan dengan skor terendah adalah pertanyaan mengenai ada atau tidaknya penyuluhan mengenai kelapa sawit di desa-desa penelitian tersebut. Skor yang didapat untuk pertanyaan tersebut adalah 56. Petani kelapa sawit di desa penelitian mengharapkan adanya kegiatan penyuluhan kelapa sawit untuk meningkatkan pengetahuan petani mengenai budidaya kelapa sawit secara baik dan benar sehingga kualitas yang dihasilkan juga bagus.

\section{B. Aspek Afektif Petani Terhadap Kebijakan Pabrik Kelapa Sawit}

Respon petani ditinjau dari aspek afektif menyatakan lebih banyak petani yang merespon positif yaitu sebanyak 36 petani $(66,7 \%)$, sedangkan sisanya yaitu 18 petani $(33,3 \%)$ merespon negatif. Persentase pada kedua jenis respon tersebut didapatkan berdasarkan rata-rata persentase dari pilihan jawaban yang dipilih responden, yaitu pilihan setuju (55,6\%), pilihan kurang setuju (19,7\%) dan pilihan tidak setuju $(24,7 \%)$. Berdasarkan hasil kuesioner yang dilakukan analisis, dari 6 pertanyaan yang diajukan skor jawaban tertinggi adalah pertanyaan mengenai kebijakan berat minimal tandan untuk masuk ke dalam pabrik kelapa sawit yaitu $8 \mathrm{Kg}$. Skor jawaban yang didapat untuk pertanyaan tersebut adalah 132. Mayoritas petani setuju terhadap kebijakan berat tandan tersebut dikarenakan tanaman kelapa sawit yang dibudidayakan menghasil TBS dengan berat lebih dari $8 \mathrm{Kg}$.

Pertanyaan yang diajukan dengan skor terendah adalah pertanyaan mengenai harga jual yang diterima petani berdasarkan kualitas TBS yang dipanen. Skor jawaban yang didapat untuk pertanyaan tersebut adalah 104. Alasan petani menjawab dengan mayoritas tidak setuju adalah petani tetap menginginkan harga jual yang normal dan tidak memberikan harga berdasarkan kualitas karena jika petani mendapat harga yang rendah (TBS tidak sesuai kebijakan) maka pendapatan petani akan berkurang. Harga jual yang rendah juga untuk memberikan efek jera kepada petani agar petani memanen TBS sesuai dengan kebijakan pabrik.

\section{Aspek Psikomotorik (partisipasi) Petani terhadap Kebijakan Pabrik Kelapa Sawit}

Respon petani dilihat dari aspek psikomotorik menyatakan lebih banyak petani yang merespon positif yaitu sebanyak 35 petani $(64,8 \%)$, sedangkan sisanya yaitu 19 petani $(35,2 \%)$ merespon negatif. Berdasarkan hasil analisis aspek psikomotorik yang dilakukan terhadap 54 petani sampel diketahui bahwa sebanyak 35 petani $(64,8 \%)$ merespon positif. Berdasarkan hasil kuesioner yang telah dianalisis, dari 4 pertanyaan yang diajukan skor jawaban tertinggi adalah pertanyaan mengenai lama buah menginap setelah dipanen. Skor jawaban yang didapat untuk pertanyaan tersebut adalah 102. Mayoritas petani segera membawa TBS hasil panen kepada touke untuk dilakukan transaksi. Minoritas petani yang tidak langsung membawa TBS dikarenakan beberapa faktor seperti cuaca, tidak adanya transportasi pada saat kegiatan panen sehingga petani terpaksa membiarkan buah menginap lebih lama di lokasi panen. Pertanyaan yang diajukan dengan skor terendah adalah pertanyaan mengenai panjang gagang TBS saat panen. Skor yang didapat untuk pertanyaan tersebut adalah 73. Mayoritas petani lebih banyak membiarkan gagang tandan berukuran panjang dibandingkan dengan memotong pendek.

Secara keseluruhan respon petani berdasarkan aspek kognitif, afektif dan psikomotorik yang dinilai adalah positif. Secara umum petani mengetahui kebijakan pabrik, menyetujui kebijakan tersebut dan mempraktikkannya di lapangan dalam melakukan panen kelapa sawit. Walaupun ada beberapa petani minoritas yang tidak mengetahui atau ragu-ragu kebijakan 
pabrik, kurang setuju atau tidak setuju dengan kebijakan pabrik dan masih keliru dalam mempraktikkannya.

\section{Frekuensi dan Persentase Petani Berdasarkan Kebijakan Pabrik Kelapa Sawit}

Frekuensi dan persentase petani berdasarkan setiap kebijakan pabrik kelapa sawit akan dijelaskan pada tabel 1 .

Tabel 1. Frekuensi dan Presentase Petani Berdasarkan Kebijakan Pabrik Kelapa Sawit

\begin{tabular}{llrr}
\hline No & \multicolumn{1}{c}{ Kebijakan } & Frekuensi (orang) & Persentase (\%) \\
1 & Fraksi Panen & 20 & \\
& F-00, F-0, F-1 & 0 & 37 \\
& F-4, F-5 & 34 & 0 \\
& F-2, F-3 & & 63 \\
2 & Berat Tandan & 16 & 29,6 \\
& $<8 \mathrm{~kg}$ & 38 & 70,4 \\
& $>8 \mathrm{~kg}$ & & 11,1 \\
3 & Buah Menginap & 6 & 88,9 \\
& $>24$ jam & 48 & 7,4 \\
& <24 jam & & 92,6 \\
\hline & Panjang Gagang & 4 & \\
& $0-2,5 \mathrm{~cm}$ & 50 & \\
\hline
\end{tabular}

Sumber: Data Primer (diolah), 2017

Tabel 1 menyatakan bahwa petani berada pada 2 fraksi panen yaitu F-00, F-0, F-1 dan F-2, F-3 untuk kebijakan fraksi panen. Sebanyak 20 petani yang memanen pada F-00, F-0 dan F-1 memiliki alasan mengapa petani memanen pada fraksi tersebut seperti takut pencurian buah, tidak sabar dalam memanen, butuh uang lebih cepat, dan lain-lain. Tidak ada petani yang memanen pada F-4, F-5 dikarenakan petani cenderung tidak mau menunggu lebih lama untuk memanen TBS. Jika semakin lama petani membiarkan buah matang di pohon kelapa sawit maka akan semakin lama petani mendapatkan uang untuk mencukupi kebutuhan hidup sehari-hari. Pengutipan berondolan juga dilakukan oleh petani, karena berondolan yang dikutip akan semakin menambah timbangan TBS petani.

Pada kebijakan berat tandan, mayoritas petani memanen pada berat tandan $>8 \mathrm{Kg}$. Sebanyak 16 petani yang memanen dengan berat tandan $<8 \mathrm{Kg}$ beralasan bahwa kelapa sawit yang ditanam masih muda sehingga buah yang dipanen adalah buah pasir, kekurangan pupuk, dan sebagainya.

Mayoritas petani tidak membiarkan TBS menginap lebih lama di lokasi panen $(88,9 \%)$. Hal ini menunjukkan bahwa lebih banyak petani yang mengikuti kebijakan pabrik kelapa sawit terkait berapa lama buah dapat menginap yaitu $<24$ jam. Buah yang menginap lebih lama akan menyebabkan buah tidak langsung terangkut menuju pabrik dan akan membusuk. Faktor yang mempengaruhi petani tidak segera membawa TBS seperti cuaca yang tidak mendukung, tidak adanya transportasi pada saat kegiatan panen sehingga membuat petani terpaksa membiarkan TBS menginap lebih lama.

Mayoritas petani memotong gagang TBS $>2,5 \mathrm{~cm}(92,6 \%)$ dibandingkan petani yang memotong gagang tandan $0-2,5 \mathrm{~cm}(7,4 \%)$. Mayoritas petani juga tidak memotong tandan mereka berbentuk huruf $\mathrm{V}$. Pembentukan gagang huruf $\mathrm{V}$ bertujuan untuk memudahkan petani memberi tanda kepemilikan pada TBS, sehingga saat pengumpulan TBS di lokasi TPH 
petani mengetahui TBS miliknya. Hal ini menunjukkan bahwa kebijakan pabrik kelapa sawit yang sering dilanggar petani adalah panjang gagang TBS.

\section{Faktor yang Mempengaruhi Respon Petani}

\section{A. Model Analisis Regresi Logistik Biner}

Tabel 2. Hasil Analisis Regresi Logistik Biner

\begin{tabular}{lllr}
\hline No & Variabel & Simbol & Nilai $(\boldsymbol{\beta})$ \\
1 & Konstanta & Co & 3,104 \\
2 & Usia & $\mathrm{X}_{1}$ & $-2,700$ \\
3 & Pendidikan & $\mathrm{X}_{2}$ & 2,129 \\
4 & Pengalaman & $\mathrm{X}_{3}$ & 0,418 \\
5 & Luas Lahan & $\mathrm{X}_{4}$ & 0,512 \\
6 & Jumlah Tanggungan & $\mathrm{X}_{5}$ & $-1,416$ \\
\hline
\end{tabular}

Sumber: Data Primer (diolah) oleh SPSS 2.1, 2017

Berdasarkan tabel 2, diperoleh persamaan regresi logistik biner sebagai berikut:

$$
\mathrm{g}(\mathrm{x})=\mathbf{3 , 1 0 4}-2,7 \mathrm{X}_{1}+\mathbf{2 , 1 2 9} \mathrm{X}_{2}+\mathbf{0 , 4 1 8} \mathrm{X}_{3}+\mathbf{0 , 5 1 2} \mathrm{X}_{4}-\mathbf{1 , 4 1 6} \mathrm{X}_{5}
$$

Nilai konstanta yang didapatkan berdasarkan uji analisis regresi logistik biner adalah 3,104 . Hal ini menyatakan bahwa rata-rata respon petani terhadap kebijakan pabrik kelapa sawit adalah sebesar 3,104 sebelum dipengaruhi oleh usia, tingkat pendidikan, pengalaman berusaha tani, luas lahan dan jumlah tanggungan petani.

\section{B. Uji Signifikansi Parameter}

Uji signifikansi parameter dilakukan untuk mengetahui taksiran parameter yang diperoleh berpengaruh secara signifikan atau tidak terhadap model.

\section{Uji Serentak (Uji G)}

Hasil analisis dengan menggunakan uji $\mathrm{G}$ untuk melihat secara bersama-sama pengaruh respon petani $(\mathrm{Y})$ terhadap variabel-variabel terikat $(\mathrm{X})$ yaitu usia, pendidikan, pengalaman berusaha tani, luas lahan dan jumlah tanggungan. Uji serentak yang dilakukan merupakan uji rasio likelihood. Berdasarkan hasil SPSS, didapatkan nilai $p$-value sebesar 0,011. Dengan menggunakan tingkat signifikansi $\alpha$ sebesar 0,05 maka nilai $p$-value yang didapat lebih kecil dari tingkat signifikansi ( $p$-value $<\alpha$ ). Maka $\mathrm{H}_{0}$ ditolak sehingga dapat disimpulkan (Paling tidak terdapat satu variabel dari variabel usia, pendidikan, pengalaman kerja, luas lahan dan jumlah tanggungan yang berpengaruh terhadap respon petani.

\section{Uji Parsial (Uji Wald)}

Tabel 3. Uji Signifikansi Parameter Secara Parsial

\begin{tabular}{lllrr}
\hline No & Variabel & Simbol & P-Value & \multicolumn{1}{c}{ Wald } \\
1 & Usia & $\mathrm{X}_{1}$ & 0,019 & 5,474 \\
2 & Pendidikan & $\mathrm{X}_{2}$ & 0,004 & 8,300 \\
3 & Pengalaman & $\mathrm{X}_{3}$ & 0,365 & 0,821 \\
4 & Luas Lahan & $\mathrm{X}_{4}$ & 0,363 & 0,827 \\
5 & Jumlah Tanggungan & $\mathrm{X}_{5}$ & 0,108 & 2,588 \\
\hline
\end{tabular}

Sumber: Data Primer (diolah) oleh SPSS 2.1, 2017

\section{a. Variabel Usia $\left(\mathbf{X}_{1}\right)$}

Nilai koefisien regresi yang didapat untuk variabel usia adalah $-2,700$ artinya bahwa setiap penambahan usia satu tahun maka akan menurunkan respon petani sebesar $2,7 \%$. 
Secara parsial, variabel usia berpengaruh nyata terhadap respon petani dibuktikan dengan nilai $p$-value < nilai signifikansi $(0,019<0,05)$. Hal ini menyatakan bahwa semakin tua umur petani maka akan semakin rendah respon petani terhadap kebijakan pabrik kelapa sawit. Sehingga dapat disimpulkan bahwa tolak $\mathrm{H}_{0}$ dan terima $\mathrm{H}_{a}$. Fakta dilapangan menunjukkan bahwa petani dengan usia tua lebih susah memahami jika diberikan penjelasan terkait kebijakan pabrik kelapa sawit. Petani berusia tua cenderung mengandalkan pengalaman mereka dibandingkan menerima informasi baru. Walaupun informasi yang diberikan adalah informasi yang bermanfaat bagi kehidupan petani, tetapi petani tua masih saja sulit menerima informasi baru tersebut.

b. Variabel Pendidikan $\left(\mathbf{X}_{2}\right)$

Nilai koefisien regresi yang didapat untuk variabel pendidikan adalah 2,129 artinya bahwa setiap penambahan 1 tahun pendidikan, maka akan menaikkan respon petani sebesar $2,129 \%$. Secara parsial, variabel pendidikan berpengaruh nyata terhadap respon petani yang dibuktikan dengan nilai $p$-value < nilai signifikansi $(0,004<0.05)$. Hal ini menyatakan bahwa semakin tinggi tingkat pendidikan petani, maka akan semakin tinggi pula respon petani terhadap kebijakan pabrik kelapa sawit. Sehingga dapat disimpulkan bahwa tolak $\mathrm{H}_{0}$ dan terima $\mathrm{H}_{\mathrm{a}}$. Fakta di lapangan juga menunjukkan hasil yang kurang sesuai dengan hasil analisis dimana tidak banyak petani yang memiliki pendidikan diatas 12 tahun, rata-rata petani berada pada jenjang pendidikan $6-12$ tahun. Tetapi petani merespon positif terhadap kebijakan pabrik. Hal ini terjadi karena jenjang pendidikan petani di desa penelitian masuk dalam kategori sedang sehingga petani masih dapat menerima informasi baru.

\section{c. Variabel Pengalaman $\left(\mathbf{X}_{3}\right)$}

Nilai koefisien regresi yang didapat untuk variabel pengalaman adalah sebesar 0,418 artinya bahwa setiap penambahan pengalaman selama 1 tahun maka akan menaikkan respon petani sebesar $0,418 \%$. Secara parsial, variabel pengalaman tidak berpengaruh nyata terhadap respon petani. Nilai p-value yang didapatkan lebih besar daripada nilai signifikansi ( $p$-value $>$ nilai sig) yaitu $0,365>0,05$. Hal ini menyatakan walaupun semakin tinggi pengalaman yang dimiliki petani, maka tidak mempengaruhi respon petani terhadap kebijakan pabrik kelapa sawit. Sehingga dapat disimpulkan bahwa terima $\mathrm{H}_{0}$ dan tolak $\mathrm{H}_{\mathrm{a}}$. Fakta di lapangan menunjukkan hal yang tidak sesuai dengan Teori Soekartawi, dimana lama atau tidaknya pengalaman petani tidak mempengaruhi keputusan petani untuk mengikuti kebijakan pabrik kelapa sawit. Hal ini disebabkan oleh pengalaman petani dalam berkebun kelapa sawit masih tergolong baru dikarenakan sebelumnya petani di desa penelitian berkebun Karet, sehingga pengalaman petani dalam hal kelapa sawit masih cenderung sedikit, sehingga pengalaman tidak berpengaruh nyata terhadap respon petani.

\section{d. Variabel Luas Lahan $\left(\mathbf{X}_{4}\right)$}

Nilai koefisien regresi yang didapat untuk variabel luas lahan adalah 0,512 artinya bahwa setiap penambahan luas lahan sebesar 1 ha, maka akan menaikkan respon petani sebesar $0,512 \%$. Secara parsial, variabel luas lahan tidak berpengaruh nyata terhadap respon petani. Hal ini diketahui dari nilai $p$-value yang didapatkan berdasarkan uji wald lebih besar dibandingkan dengan nilai signifikansi, yaitu 0,363>0,05. Hal ini menunjukkan bahwa walaupun semakin luas lahan yang dimiliki oleh petani, maka tidak mempengaruhi respon petani terhadap kebijakan pabrik kelapa sawit. Sehingga dapat disimpulkan bahwa terima $\mathrm{H}_{0}$ dan tolak $\mathrm{H}_{\mathrm{a}}$. Fakta di lapangan menyatakan hal yang sesuai dengan hasil analisis. Hal ini menunjukkan luas lahan yang dimiliki petani tidak mempengaruhi keputusan petani untuk mengikuti kebijakan pabrik atau tidak. 


\section{e. Variabel Jumlah Tanggungan $\left(\mathbf{X}_{5}\right)$}

Nilai koefisien regresi yang didapat untuk variabel jumlah tanggungan adalah

1,416 artinya bahwa setiap penambahan jumlah tanggungan petani, maka akan menurunkan respon petani sebesar $1,416 \%$. Secara parsial, variabel jumlah tanggungan tidak berpengaruh nyata terhadap respon petani berdasarkan nilai $p$-value yang didapatkan yaitu 0,108. jika dibandingkan dengan nilai signifikansi, maka 0,108>0,05. Hal ini menyatakan bawa walaupun jumlah tanggungan yang dimiliki petani kecil, maka tidak mempengaruhi respon petani terhadap kebijakan pabrik kelapa sawit. Sehingga dapat disimpulkan bahwa terima $\mathrm{H}_{0}$ dan tolak $\mathrm{H}_{\mathrm{a}}$.

\section{Uji Kesesuaian Model}

Uji ini digunakan untuk mengevaluasi kesesuaian model yang dilihat berdasarkan nilai dari uji Hosmer dan Lemeshow. Uji kesesuaian model yang telah dilakukan menunjukkan bahwa p-value dari respon petani adalah sebesar 0,666. Nilai ini lebih besar dari taraf signifikansi $\alpha$ yang ditetapkan yaitu 0,05 , karena $p$-value yang didapat lebih besar dari $\alpha$ maka $\mathrm{H}_{0}$ tidak dapat ditolak sehingga dapat disimpulkan jika model sesuai dengan data.

Selanjutnya uji kesesuaian model pada regresi logistik biner juga dapat dilihat dari nilai pseudo $R^{2}$ (negelkerke $R^{2}$ ). Dalam penelitian ini nilai negelkerke $R^{2}$ sebesar 0,408 atau 40,8\%. Ini berarti variabel usia, pendidikan, pengalaman kerja, luas lahan dan jumlah tanggungan mampu menjelaskan respon petani sebesar 40,8\%.

\section{Tingkat Pendapatan Berdasarkan Respon Petani}

Pendapatan petani kelapa sawit dalam hal ini hanya dihitung berdasarkan harga jual yang diterima petani dikurangi biaya panen yang dikeluarkan petani seperti upah tenaga kerja, biaya transportasi dan penyusutan alat panen. Rata-rata biaya panen yang dikeluarkan petani dan penerimaan petani akan dijelaskan pada tabel 4, tabel 5 dan tabel 6 .

Tabel 4. Jumlah Petani Berdasarkan Biaya Panen

\begin{tabular}{llrrr}
\hline No & \multicolumn{1}{c}{$\begin{array}{c}\text { Jenis Biaya } \\
1\end{array}$} & $\begin{array}{c}\text { Jumlah petani } \\
\text { positif (orang) }\end{array}$ & $\begin{array}{c}\text { Jumlah Petani } \\
\text { Negatif (orang) }\end{array}$ & \multicolumn{2}{c}{$\begin{array}{c}\text { Biaya } \\
\text { (Rp/Kg) }\end{array}$} \\
2 & 35 & 19 & 200 \\
& Transportasi & & & 100 \\
& Mobil & 15 & 5 & 50 \\
& Sepeda Motor & 15 & 9 & 25 \\
& Becak barang & 3 & 2 & 6 \\
Angkong & 2 & 3 & 3.125 \\
3 & Alat Panen & 11 & 4 & 2.125 \\
Gancu, dodos, egrek & 6 & 6 & 1.562 \\
\hline & Gancu, egrek & 18 & 9 &
\end{tabular}

Sumber : Data Primer (diolah), 2017

Tabel 5. Perhitungan Rata-Rata Biaya Panen Petani Berdasarkan Respon

\begin{tabular}{crrrr}
\hline Kategori & $\begin{array}{c}\text { Biaya Transportasi } \\
(\mathbf{R p})\end{array}$ & $\begin{array}{c}\text { Biaya Tenaga } \\
\text { Kerja (Rp) }\end{array}$ & $\begin{array}{c}\text { Penyusutan Alat } \\
\text { Panen (Rp) }\end{array}$ & $\begin{array}{c}\text { Total Biaya } \\
\text { Panen (Rp) }\end{array}$ \\
\hline Positif & 136.414 & 440.046 & 2.121 & 5785810 \\
Negatif & 115.278 & 371.863 & 2.21 & 489.262 \\
\hline
\end{tabular}

Sumber : Data Primer (diolah), 2017 
Biaya panen yang dikeluarkan diantara kedua kategori petani juga berbeda. Petani respon positif mengeluarkan lebih banyak biaya panen. Hal ini disebabkan oleh petani yang ingin mendapatkan kualitas TBS yang baik sehingga petani akan melakukan proses panen yang baik dan alat panen yang sesuai. Tidak semua petani memiliki alat panen lengkap seperti gancu, egrek dan dodos. Fakta dilapangan menunjukkan masih ada petani yang salah dalam memanfaatkan alat panen, seperti memanen tanaman kelapa sawit yang masih berumur 8 tahun dengan tinggi <10 meter menggunakan egrek. Padahal menurut Pardamean (2008) egrek adalah alat panen kelapa sawit dengan tinggi tanaman lebih dari 10 meter.

Upah tenaga kerja antara petani respon positif dan petani respon negatif adalah sama yaitu Rp 200/Kg. Semua petani di desa penelitian yang menggunakan jasa tenaga kerja panen memberikan upah yang sama. Upah tenaga kerja yang sama dapat menghindari adanya kecemburuan antar tenaga kerja yang satu dengan yang lain. Sedangkan petani yang menggunakan tenaga kerja sendiri perhitungan upah tenaga kerja tetap sama. Hal ini dikarenakan petani di desa penelitian menggunakan corak komersial (bisnis) sehingga walaupun tenaga kerja yang digunakan adalah tenaga kerja sendiri, perhitungan upah tetap dilakukan. Dapat dikatakan petani membayar upah untuk dirinya sendiri.

Rata-rata biaya transportasi adalah $\mathrm{Rp} 62 / \mathrm{Kg}$. Transportasi yang paling banyak digunakan adalah mobil dimana petani lebih memilih membayar upah sewa dibandingkan membawa hasil panen sendiri. Pertimbangan lain dalam pemilihan alat transportasi adalah jarak dari kebun menuju tempat pengumpulan hasil. Petani yang memiliki kebun dengan jarak yang dekat tempat pengumpulan hasil, akan membawa hasil panen sendiri menggunakan angkong, sepeda motor ataupun becak.

Tabel 6. Perhitungan Rata-Rata Pendapatan Petani Berdasarkan Respon

\begin{tabular}{|c|c|c|c|c|}
\hline Kategori & $\begin{array}{c}\text { Luas Lahan } \\
\text { (Ha) }\end{array}$ & $\begin{array}{c}\text { Produksi } \\
\text { (Kg/Panen) }\end{array}$ & $\begin{array}{l}\text { Harga Jual } \\
\quad(\mathbf{R p})\end{array}$ & Pendapatan (Rp) \\
\hline Positif & 2,7 & 2.200 & 850 & 1.870 .000 \\
\hline Negatif & 2,4 & 1.859 & 500 & 929.500 \\
\hline
\end{tabular}

Sumber : Data Primer (diolah), 2017

Sehingga pendapatan bersih yang diterima petani kelapa sawit berdasarkan respon adalah sebagai berikut:

a. Petani respon positif

Pendapatan = Nilai Produksi $(\mathrm{Rp})-$ Biaya Panen $(\mathrm{Rp})$

$=\operatorname{Rp} 1.870 .000-\operatorname{Rp} 578.581$

$=\operatorname{Rp} 1.291 .419$

$=\operatorname{Rp} 478.303 / \mathrm{Ha}$

b. Petani respon negatif

Pendapatan $=$ Nilai Produksi $(\mathrm{Rp})-$ Biaya Panen $(\mathrm{Rp})$

$=\operatorname{Rp} 929.500-\operatorname{Rp} 489.262$

$=\operatorname{Rp} 440.238$

$=\operatorname{Rp} 183.433 / \mathrm{Ha}$

Berdasarkan hasil perhitungan diatas, diketahui bahwa petani dengan respon positif memiliki pendapatan lebih tinggi dibandingkan petani dengan respon negatif (terima $\mathrm{H}_{\mathrm{a}}$, tolah $\mathrm{H}_{0}$ ). Hal ini didukung dari harga jual berbeda yang diberikan touke kepada petani yaitu $\mathrm{Rp}$ 850/kg untuk petani respon positif dan Rp 500/kg untuk petani respon negatif. Walaupun biaya panen yang dikeluarkan petani respon positif lebih tinggi dibandingkan petani respon negatif, tetapi tidak mempengaruhi tingginya pendapatan yang diterima petani respon positif 


\section{Kesimpulan}

\section{KESIMPULAN DAN SARAN}

Adapun kesimpulan dari penelitian ini adalah sebagai berikut:

1. Respon petani kelapa sawit terhadap kebijakan pabrik kelapa sawit di Kecamatan Indra Makmu Kabupaten Aceh Timur berdasarkan penilaian 3 aspek yaitu kognitif, afektif dan psikomotorik adalah positif. Aspek kognitif sebanyak 32 petani (59,3\%), aspek Afektif sebanyak 36 petani $(66,7 \%)$ dan aspek psikomotorik sebanyak 35 petani $(64,8 \%)$. Kebijakan yang paling banyak diikuti petani adalah kebijakan buah menginap yaitu 48 petani $(88,9 \%)$, sedangkan kebijakan yang sedikit diikuti petani adalah kebijakan panjang gagang yaitu sebanyak 50 petani $(92,6 \%)$

2. Faktor usia dan tingkat pendidikan berpengaruh nyata terhadap respon petani dimana nilai $p$-value < nilai signifikansi yaitu untuk usia $0,019<0,05$ dan untuk pendidikan $0,004<0.05$ yaitu tolak $\mathrm{H}_{0}$ dan terima $\mathrm{H}_{\mathrm{a}}$. Sedangkan faktor pengalaman, luas lahan dan jumlah tanggungan tidak berpengaruh nyata terhadap respon petani.

3. Tingkat pendapatan petani respon positif lebih tinggi dibandingkan petani respon negatif, disebabkan adanya perbedaan harga jual yang diterima petani yaitu $\mathrm{Rp} 850 / \mathrm{Kg}$ untuk petani yang mengikuti kebijakan pabrik (respon positif) dan $\mathrm{Rp} 500 / \mathrm{Kg}$ untuk petani yang tidak mengikuti kebijakan pabrik (petani negatif). Hal ini dapat dilihat dari perhitungan rata-rata pendapatan petani yaitu Rp 478.303/Ha untuk petani respon positif dan $\mathrm{Rp}$ 183.433/Ha untuk petani respon negatif.

\section{Saran}

1. Bagi petani kelapa sawit di Kecamatan Indra Makmu Kabupaten Aceh Timur, mengingat bahwa kualitas TBS yang dipanen akan mempengaruhi kualitas CPO yang dihasilkan dari TBS tersebut dan pendapatan yang diterima petani yang mengikuti kebijakan pabrik, sebaiknya petani mengikuti kebijakan pabrik agar petani dapat menerima pendapatan yang lebih tinggi. Semakin bagus kualitas TBS yang dijual maka akan semakin tinggi pula pendapatan yang diterima. TBS yang berkualitas akan menghasilkan minyak yang berkualitas pula.

2. Bagi pemerintah ataupun dinas terkait, untuk meningkatkan respon petani perlu diadakan penyuluhan kelapa sawit agar petani semakin memahami standar sistem panen yang baik sehingga secara keseluruhan petani dapat memberikan TBS yang berkualitas.

3. Diharapkan pada penelitian selanjutnya agar dapat menggunakan metode perhitungan respon yang lebih mendetail agar penelitian semakin baik dan semakin ilmiah.

\section{DAFTAR PUSTAKA}

Arfah. 2013. Analisis Komparatif Pendapatan Usahatani Padi Sawah Sistem Tabela Dan Sistem Tapin (Di Desa Dolago Kecamatan Parigi Selatan Kabupaten Parigi Moutong). e-J. Agrotekbis 1 (3) : 244-249, Agustus 2013 ISSN : 2338-3011.

[BPS] Badan Pusat Statistik Provinsi Aceh. 2011. Aceh Dalam Angka 2015. http://aceh.bps.go.id/linkTableDinamis/view/id/81 [8 Maret 2017].

Jatmiko. 2012. Kebijakan Pemerintah Daerah Kabupaten Purworejo Dalam Pelestarian Benda Cagar Budaya Sebagai Kearifan Lokal (Studi Pada Dinas Pendidikan Dan Kebudayaan). E-CIVICS. 1/3 TAHUN 2012.

Kurniawan Rahmat. 2014. Analisis Faktor Faktor Yang Mempengaruhi Pendapatan Usahatani Sawit Anggota Kud Mukti Jaya Di Kecamatan Sungai Lilin Musi Banyuasin. 
Societa: Jurnal Ilmu-Ilmu Agribisnis. SOCIETA III - 2 : 75 - 82, Desember 2014 ISSN 2301- 4180.

Muttakin, Dedi. 2014. Faktor-Faktor Sosial Ekonomi Yang Mempengaruhi Pedapatan Usahatani Kelapa Sawit Pola Swadaya Di Desa Kepau Jaya Kabupaten Kampar. Jurnal RAT Vol.3. No.1 ISSN : 2252-9608.

Pardamean Maruli. 2012. Sukses membuka kebun dan pabrik kelapa sawit. Penerbit swadaya. Jakarta.

Pasaribu Agustina Irene 2013. Pola Kemitraan Dan Pendapatan Usahatani Kelapa Sawit: Kasus Kemitraan Usahatani Kelapa Sawit Antara Pt Perkebunan Nusantara VII Unit Usaha Bekri Dengan Petani Mitra Di Desa Tanjung Jaya, Kecamatan Bangun Rejo, Kabupaten Lampung Tengah. Digilib Unila. Jiia, Volume 1, No. 4.

Pontoh, Sisilia Carolina. 2014. Perbandingan Pendapatan Petani Padi Sawah Peserta Dan Bukan Peserta Pasar Lelang Komoditi Agro (PLKA) Di Kelurahan Kiniar Kecamatan Tondano Timur. Skripsi. Jurusan Sosial Ekonomi Fakultas Pertanian Universitas Sam Ratu langi.

Pratiwi Efrita Diariani. 2012. Perilaku Petani Dalam Mengelola Lahan Pertanian Di Kawasan Rawan Bencana Longsor (Studi Kasus Desa Sumberejo Kecamatan Batur Kabupaten Banjarnegara Jawa Tengah). Jurnal Bumi Indonesia. Volume 1, Nomor 3, Tahun 2012.

Putri, Resna NK. 2012. Respon Petani Apel Terhadap Industrialisasi Pertanian (Kasus Di Desa Poncokusomo Kecamatan Poncokusomo Kabupaten Malang. SEPA: Vol. 8 No. 2 :92-103 ISSN:1829-9946.

Rahmawati Aprilia. 2016. Respon Petani Terhadap Pelayanan Kredit Umum Pedesaaan Rakyat (Kupra) Sebagai Pengganti Kredit Usaha Rakyat (Kur) Pada Bank Rakyat Indonesia (Bri) Unit Putra Rumbia Kabupaten Lampung Tengah. Skripsi. Fakultas Pertanian Universitas Lampung.

Rizieq, Rahmatullah. 2008. Analisis Respon Petani Terhadap Program Pengembangan Kawasan Uaha Agribisnis Terpadu (KUAT) Di Provinsi Kalimantan Barat. Jurnal Ilmu Pengetahuan Sosial, Vol X, :22-34.

Sembiring, Fandi S. 2013. Sikap Dan Perilaku Petani Terhadap Kinerja Perkumpulan Petani Pemakai Air (P3a) Citra Mandiri Di Kelurahan Tualang (Kasus : P3a Citra Mandiri Kelurahan Tualang, Kecamatan Perbaungan, Kabupaten Serdang Bedagai). Skripsi. Program Studi Agribisnis Fakultas Pertanian USU.

Stiawan, A,. Sri wahyuningsih dan Eka Dewi Nurjayanti. 2014. Faktor-Faktor Yang Mempengaruhi Pendapatan Petani Karet. Mediaagro. Vol.10 No2. 2014:69-80.

Wijayanti Alvitri. 2015. Respons Petani Terhadap Inovasi Budidaya Dan Pemanfaatan Sorgum Di Kecamatan Srandakan Kabupaten Bantul (Farmer Response to Innovation in Cultivation and Use of Sorghum in Srandakan Sub District Bantul Regency). Agro Ekonomi Vol. 26/No. 2, Desember 2015 